\title{
Estrogen Receptor Ligands: A Review (2013-2015)
}

\author{
Shabnam Farzaneh and Afshin Zarghi * \\ Department of Medicinal Chemistry, School of Pharmacy, Shahid Beheshti University of Medical Sciences, \\ P.O. Box 14155-6153, Tehran 19919-5338, Iran; Shabnamfa92@gmail.com \\ * Correspondence: zarghi@sbmu.ac.ir; Tel.: +98-21-8820096; Fax: +98-21-8866-5341
}

Academic Editor: Thomas Erker

Received: 24 November 2015; Accepted: 17 January 2016; Published: 13 April 2016

\begin{abstract}
Estrogen receptors (ERs) are a group of compounds named for their importance in both menstrual and estrous reproductive cycles. They are involved in the regulation of various processes ranging from tissue growth maintenance to reproduction. Their action is mediated through ER nuclear receptors. Two subtypes of the estrogen receptor, $\mathrm{ER} \alpha$ and $\mathrm{ER} \beta$, exist and exhibit distinct cellular and tissue distribution patterns. In humans, both receptor subtypes are expressed in many cells and tissues, and they control key physiological functions in various organ systems. Estrogens attract great attention due to their wide applications in female reproductive functions and treatment of some estrogen-dependent cancers and osteoporosis. This paper provides a general review of ER ligands published in international journals patented between 2013 and 2015. The broad physiological profile of estrogens has attracted the attention of many researchers to develop new estrogen ligands as therapeutic molecules for various clinical purposes. After the discovery of the ER $\beta$ receptor, subtype-selective ligands could be used to elicit beneficial estrogen-like activities and reduce adverse side effects, based on the different distributions and relative levels of the two ER subtypes in different estrogen target tissues. Therefore, recent literature has focused on selective estrogen ligands as highly promising agents for the treatment of some types of cancer, as well as for cardiovascular, inflammatory, and neurodegenerative diseases. Estrogen receptors are nuclear transcription factors that are involved in the regulation of many complex physiological functions in humans. Selective estrogen ligands are highly promising targets for treatment of some types of cancer, as well as for cardiovascular, inflammatory and neurodegenerative diseases. Extensive structure-activity relationship studies of ER ligands based on small molecules indicate that many different structural scaffolds may provide high-affinity compounds, provided that some basic structural requirements are present.
\end{abstract}

Keywords: estrogens; estrogen receptor $\alpha$; estrogen receptor $\beta$; ligand; patent; cancer

\section{Introduction}

\subsection{Estrogen}

Estrogens are a group of compounds named for their importance in both menstrual and estrous reproductive cycles. They are primary female sex hormones. Estrogens readily diffuse across the cell membrane. Inside the cell, they bind and activate estrogen receptors.

\section{Estrogen Receptor Subtypes}

Two subtypes of the estrogen receptor, ER $\alpha$ and $E R \beta$, exist and exhibit distinct cellular and tissue distribution patterns. In humans, both receptor subtypes are expressed in many cells and tissues, and they control key physiological functions in various organ systems such as reproductive, skeletal, cardiovascular, and central nervous systems. ER $\alpha$ is mainly expressed in the mammary gland, uterus, ovary (thecal cells), bone, male reproductive organs (testes and epididymis), prostate (stroma), 
liver, and adipose tissue. In contrast, ER $\beta$ is predominant in the prostate (epithelium), bladder, ovary (granulosa cells), colon, adipose tissue, and immune system. However, both subtypes are markedly expressed in the cardiovascular and central nervous systems. Estradiol and hormone replacement therapies target both the ERs, but this often leads to an increased risk of breast and endometrial cancers, and thromboembolism. Also, selective estrogen receptor modulators (SERMs), structurally, are various compounds that interact with intracellular estrogen receptors in different target organs as ER agonists or antagonists [1]. Ideal SERMs would possess antagonist activity in the mammary gland and uterus, and agonist activity in other target tissues that benefit from estrogen-like actions such as the cardiovascular, skeletal, and central nervous systems [2]. Alternatively, subtype-selective ligands could be used to elicit beneficial estrogen-like activities and reduce adverse side effects, based on the different distributions and relative levels of the two ER subtypes in the different estrogen target tissues mentioned above [3].

\subsection{Potential Clinical Applications of Estrogens}

\subsubsection{Cancer}

The role of ERs in many cancers such as breast cancer, prostate cancer, and colorectal cancer has been extensively studied. Suppression of estrogen production in the body is a treatment for breast cancer. Especially in breast cancer, activation of ER $\alpha$ by estrogens is considered to be responsible for enhanced proliferation, whereas this is counteracted by the presence of $E R \beta$, which exerts an anti-proliferative effect [4].

\subsubsection{Neuropathies}

Estrogen directly influences brain function through estrogen receptors located on neurons in multiple areas of the brain. There is considerable evidence that indicates the important role of estradiol in the central nervous system (CNS) for different kinds of diseases, including pathologies associated with depression, anxiety, and Alzheimer's disease. At neuronal synapses, estrogen increases the concentration of neurotransmitters such as serotonin, dopamine, and norepinephrine. It affects their release, reuptake, and enzymatic inactivation [5]. A recent study reported that aged female mice responded favorably to estrogen administration and exhibited greater anti-anxiety and antidepressant behavior [6].

\subsubsection{Cardiovascular Disease}

Estrogen has a number of effects on cardiovascular function and disease. The regular production of estrogens in pre-menopausal women places them at a lower risk for cardiovascular disease relative to men. However, this cardioprotective effect vanishes after menopause [7]. Several mechanisms are involved in this cardioprotective role such as the effects of estrogen on lipoprotein levels, vasomotor function, LDL oxidation, coagulation, and collagen and elastin synthesis [8].

\subsubsection{Osteoporosis}

Osteoporosis is a major health problem associated with estrogen deficiency in postmenopausal women. Many studies have indicated that estrogens play an important role in bone homeostasis, not only in women but also in men [9]. Estrogen replacement therapy (ERT) is clinically used to prevent osteoporosis.

\section{Estrogen Receptor Ligands}

ERs are nuclear transcription factors that are involved in the regulation of many complex physiological functions in humans. The term SERM describes synthetic ER ligands that display tissue-selective pharmacology. This concept was first described in 1990 [10]. As anti-estrogens, they oppose the action of estrogens in certain tissues while mimicking the action of endogenous 
estrogens in others. Over the past few years, many reviews have covered the progress in the development of estrogen receptors [11-15]. We herein provide an overview and update of compounds that have been recently reported as estrogen receptor ligands, with a particular focus on their potential clinical applications.

\section{Steroidal Ligands}

Zhang et al. reported a new series of $11 \beta$-ether-17 $\alpha$-ethinyl-3,17ß-estradiol that demonstrates strong ER antagonist activity. The ethers were particularly interesting as they were highly active anti-estrogens that were more stable than other substituents. Among these ethers, compounds $\mathbf{1}$ and $\mathbf{2}$ (Figure 1) bind very strongly to both ER $\alpha$ and ER $\beta$ [16].<smiles>CC#CC1(O)CCC2C3CCc4cc(O)ccc4C3C(CCCOC(C)C)CC21C</smiles>

1<smiles>COc1cc2c(cc1/C=C\c1cc(OC)c(OC)c(OC)c1)C1CCC3(C)C(OC(C)=O)CCC3C1CC2</smiles>

3<smiles></smiles>

5<smiles>C#CC1(O)CCC2C3CCc4cc(O)ccc4C3C(CCCOC(C)(C)C)CC21</smiles>

2<smiles>CC12CCC(=O)NC1CCC1C2CCC2(C)C1CCC2n1cnc2c(N3CCN(c4ccccc4F)CC3)nc(Cl)nc21</smiles>

4<smiles>CC12CCC3c4cc([N+](=O)[O-])c(OCCN5CCOCC5)cc4CCC3C1CCC2O</smiles>

6

Figure 1. Steroidal Ligands.

Combretastatin A4 analogues on a steroidal framework were reported to have anti-breast cancer properties. Recently, natural compounds have increasingly been used in traditional medicines. Combretastatin A4 is one of these compounds that induce apoptosis and act as an antiangiogenic agent [17]. Twenty-two analogues were synthesized by the Combretastatin A4 steroidal framework and among them, compound 3 (Figure 1) was the most active in both MCF-7 and MDA-MB-231 cells with $\mathrm{IC}_{50} 7.5 \mu \mathrm{M}$ and $5.5 \mu \mathrm{M}$ [18].

Recently, Huang et al. reported two new series of novel C6-piperazine-substituted purine steroid-nucleosides and C6-cyclo secondary amine-substituted purine steroid-nucleoside analogues. Nucleoside analogues showed an important role in the development of antitumor drugs [19-21]. Among them, C6-aminopurine derivatives had a wide range of biological properties and displayed antitumor activity [22-24]. In addition, piperazine derivatives showed a broad spectrum of biological activities, such as anticancer activity $[25,26]$. Therefore, these analogues were synthesized and evaluated for their anticancer activity. Among C6-piperazine-substituted purine steroid-nucleosides analogues, compound 4 (Figure 1) showed the best results on the MCF-7 cell line [27]. However, compound 5 (Figure 1) displayed only moderate anticancer activity against the MCF-7 cell line [28]. 
Bandyopadhyay et al. [29] also reported a new series of 2- and 4-nitroestradiol derivatives. They showed that compound 6 (Figure 1), as well as a known ER-targeting drug, 4-hydroxytamoxifen (4-HT), reduced the viability of ER-positive and ER-negative cells with similar efficacy. The toxicity exhibited by 6 was slightly better than $4-\mathrm{HT}$, with an $\mathrm{IC}_{50}$ value of approximately $2 \mu \mathrm{M}$ in breast cancer cells. These data indicate that selective novel nitroestradiol compounds effectively cause cytotoxicity in breast cancer cells and their cytotoxicity might occur in an ER-independent manner.

\section{Non-Steroidal Ligands}

\subsection{2,3-Diaryl Isoquinolinone}

A new series of 2,3-diaryl isoquinolinone derivatives were reported as anti-breast cancer agents targeting $\mathrm{ER} \alpha$ and vascular endothelial growth factor receptor 2 (VEGFR-2). ER $\alpha$ is responsible for estrogen-induced proliferation in breast cancer in which angiogenesis plays an important role in both local tumor growth and distant metastasis in many cancers [30]. Therefore, Tang et al. [31] reported a new series of compounds with characteristics of both selective estrogen receptor modulators and VEGFR-2 inhibitors. It was anticipated for these compounds with dual targets to gain more efficiency as anti-breast cancer agents with fewer side effects. VEGFR-2 inhibitors possessing an indol-2-one scaffold, such as sunitinib and YM231146, bear some structural similarities with SERMs (Figure 2). All compounds possess an aromatic scaffold and flexible side chain with a tertiary amine substituent on the end. Based upon that, 2,3-diaryl isoquinolinone derivatives were synthesized and evaluated. Among these series, compounds 7 and 8 (Figure 3) had the best affinity for ER $\alpha$ and the inhibition rates were as potent as tamoxifen. The results of a VEGFR-2 kinase inhibition assay showed that these derivatives had moderate-to-strong inhibitory activities compared with sunitinib. Compound 8 showed the best results for both ER $\alpha$ and VEGFR-2 kinase inhibition.

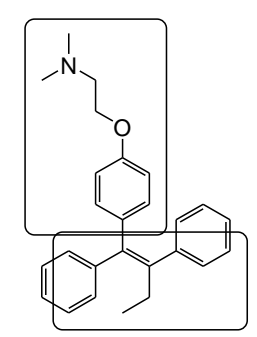

Tamoxifen

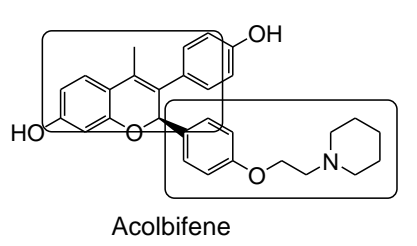

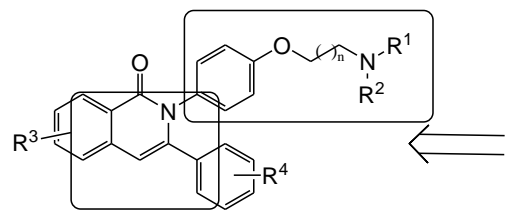

diaryl isoquinolinones

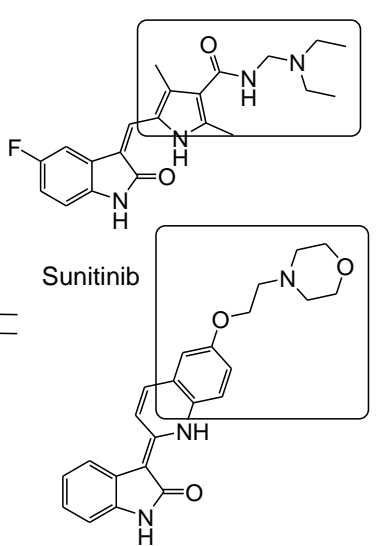

YM231146

Figure 2. Chemical structures of SERMS, VEGFR-2 inhibitors, and designed compounds [31].<smiles>O=c1c2cc(O)ccc2cc(-c2ccc(O)cc2)n1-c1ccc(OCCCN2CCCC2)cc1</smiles>

7<smiles>O=c1c2cc(O)ccc2cc(-c2ccc(O)cc2)n1-c1ccc(OCCCN2CCCCC2)cc1</smiles>

8

Figure 3. 2,3-Diaryl isoquinolinone derivatives. 


\subsection{Diphenylmethane Skeleton and Related Analogues}

Maruyama et al. [32,33] have shown that the diphenylmethane skeleton can have a steroid role. Bisphenol A has estrogenic activity and bisphenol AF and HPTE have agonist activity for $\mathrm{ER} \alpha$ with antagonist activity for $\mathrm{ER} \beta$ (Figure 4). Therefore, these compounds would bind to ER $\alpha$ in a similar manner to $17 \beta$-estradiol, but selectively for ER $\beta$. Many analogues of bisphenol A were also synthesized and their agonist and antagonist activities were evaluated. Results showed that longer linear alkyl chains at the central carbon decreased the agonistic activities for both ER $\alpha$ and $\mathrm{ER} \beta$, but increased the antagonist activities for both $\mathrm{ER} \alpha$ and $\mathrm{ER} \beta$. Among these series, compound 9 (Figure 4) displayed potent ER $\alpha$-antagonist activity with a 28 -fold selectivity over ER $\beta$. As described, central alkyl chains were critical for potent ER antagonistic activities, indicating that the hydrophobicity at the central moiety is important for strong antagonistic activity. On the other hand, sila-substitution (C/Si exchange) of existing drugs is an attractive approach to find new drug candidates. Because silicon-containing analogues are more lipophilic and larger in molecular size than their carbon analogues [34-37], a new series of sila-analogues were synthesized with the aim of increasing hydrophobicity or molecular size. However, both sila-analogues $\mathbf{1 0}$ and $\mathbf{1 1}$ (Figure 4) showed decreased activities compared with carbon derivatives [38].

Also, in 2015 Ohta et al. [39] reported the diphenylamine skeleton as ER antagonist candidates containing a basic alkylamino side chain on one of the two phenol groups of the diphenylamine agonist core structure. The results indicated that compounds with cyclic alkylamine showed higher ER-antagonistic activity than the corresponding acyclic derivatives in a cell proliferation assay using the MCF-7 cell line. Compound 12 showed the highest antiestrogenic activity $\left(\mathrm{IC}_{50}=1.3 \times 10^{-7} \mathrm{M}\right)$, being 10 times more potent than tamoxifen.<smiles>CC(C)(c1ccc(O)cc1)c1ccc(O)cc1</smiles>

Bisphenol A<smiles>Cc1cc(C(P)(P)c2ccc(O)c(C)c2)ccc1O</smiles>

9<smiles>CC(C)(c1ccc(O)cc1)C(F)(F)c1ccc(O)cc1</smiles>

Bisphenol AF<smiles>CC[Si](c1ccc(O)c(C)c1)(c1ccc(O)c(C)c1)c1ccc(O)c(C)c1</smiles>

10<smiles>Oc1ccc(C(c2ccc(O)cc2)C(Cl)(Cl)Cl)cc1</smiles>

Bisphenol HPTE<smiles>[10BH2][Si]([10BH2])(c1ccc(O)c(C)c1)c1ccc(O)c(C)c1</smiles>

11<smiles>CCCCCN(c1ccc(O)cc1)c1ccc(OCCN2CCCC2)cc1</smiles>

12

Figure 4. Diphenylmethane skeleton analogues.

\subsection{Deoxybenzoin Analogues}

Estrogenic effects of three substituted deoxybenzoins were reported by Chandrasekharan et al. [40]. These compounds were designed as CMPD3 (13, Figure 5), CMPD6 (14, Figure 5), and CMPD9 (15, Figure 5) which possess $-\mathrm{COOH},-(\mathrm{CH} 2) 4-\mathrm{CH} 3$, and $-\mathrm{CH} 3$ substitutions, respectively, on the $2^{\prime}$ 
position of the 2,4-dihydroxyphenyl ring of deoxybenzoin. Results showed that all three compounds increased the proliferation of the MCF-7 cell line and showed similar affinity for both ER $\alpha$ and ER $\beta$ receptors.<smiles>O=C(O)c1cc(O)cc(O)c1C(=O)Cc1ccc(O)cc1</smiles>

13 (CMPD3)<smiles>Cc1cc(O)cc(O)c1C(=O)Cc1ccc(O)cc1</smiles>

14 (CMPD6)<smiles>Cc1cc(O)cc(O)c1C(=O)Cc1ccc(O)cc1</smiles>

15 (CMPD9)

Figure 5. Deoxybenzoin derivatives.

\subsection{Hydrazide Derivatives}

Recently hydrazide derivatives were patented as estrogen-related receptor (ERR) ligands. Figure 6 shows the structure of this series. Most of the compounds of this group were selective estrogen-related receptor modulators or co-activator selective ligands [41].

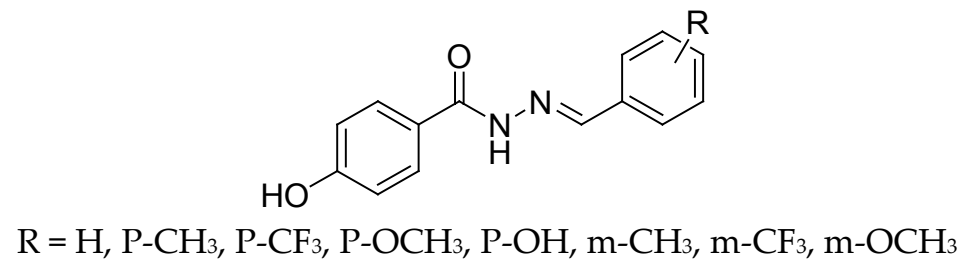

Figure 6. Hydrazide derivatives.

\subsection{Fluoren-3-one Derivatives}

Recently a new group of 7-hydroxyfluoren-3-one derivatives were reported as selective ER $\beta$, such as compounds 16-18 (Figure 7) [42,43].<smiles>C[C@@]12CC(=O)C(Cl)=C1c1ccc(O)c(Cl)c1C2</smiles>

16<smiles>CCCCC12CCC(=O)C(Br)=C1c1ccc(O)cc1C2</smiles>

17<smiles>CCCC[C@]12CCC(=O)C(Br)=C1c1cc(F)c(O)c(Cl)c1C2</smiles>

18

Figure 7. Fluoren-3-one analogues as selective ER $\beta$.

\subsection{Triphenylethylene Coumarin}

Novel triphenylethylene-coumarin hybrid derivatives containing different types and increasing numbers of amino ethoxy side chains were reported and evaluated in 2013 [44]. These derivatives were subjected to anti-proliferative tests against five tumor cells and tamoxifen were used as a positive control. The derivatives displayed a broad-spectrum and good anti-proliferative activity. Between these compounds (19-22, Figure 8), compound 19 showed the best results. Therefore, these observations suggested that: (1) the number of the amino alkyl chain on 3,4-diphenylcoumarin had considerable impact on anti-proliferative activity, and two side chains were more preferable for this activity; (2) the weaker basic amino group on the side chain indicated a detrimental influence on anti-proliferative activity. 
Also, in 2015, Smith et al. [45] patented some compounds that have a coumarin scaffold as estrogen receptor modulators. The general structure of $\mathbf{2 3}$ showed estrogen receptor antagonist activity and can also be an estrogen receptor degrader.

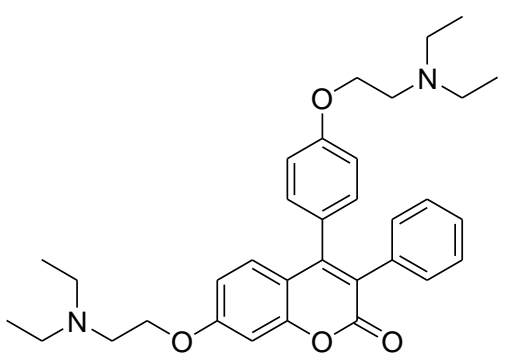

19<smiles>COc1ccc2c(-c3ccc(OCCN4CCCCC4)cc3)c(-c3ccccc3)c(=O)oc2c1</smiles>

21<smiles>O=c1oc2cc(OCCN3CCCC3)ccc2c(-c2ccc(O)cc2)c1-c1ccccc1</smiles>

20<smiles>O=c1oc2cc(OCCN3CCCCC3)ccc2c(-c2ccc(OCCN3CCCCC3)cc2)c1-c1ccc(OCCN2CCCCC2)cc1</smiles>

22

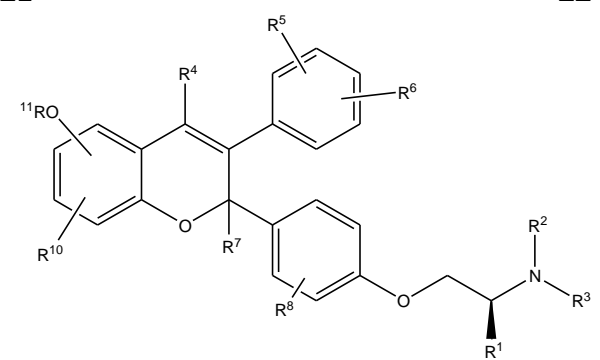

$\mathrm{R}^{1} \& \mathrm{R}^{2}=\mathrm{C}_{1}-\mathrm{C}_{6}$ alkyl, $\mathrm{C}_{1}-\mathrm{C}_{6}$ fluoro alkyl, $\mathrm{R}^{3}=\mathrm{C}_{1}-\mathrm{C}_{6}$ fluoro alkyl, $\mathrm{R}^{4-11}=-\mathrm{H}$, Halogen, $-\mathrm{CN}$

23

Figure 8. Triphenylethylene-coumarin hybrids.

\subsection{Combination of Anti-Estrogen and Receptor Tyrosine Kinase (RTK) Inhibitors}

A combination of anti-estrogen and receptor tyrosine kinase (RTK) inhibitors was patented as a useful agent for the treatment of cancer by Novartis. Receptor tyrosine kinases (RTKs) are transmembrane polypeptides that regulate developmental cell growth. A combination of fulvestrant with RTK inhibitors such as compound 24 (Figure 9) displayed significant improvement in the treatment of proliferative diseases [46].<smiles>[R]c1ccc2nc(-c3c(N)c4c(F)cccc4[nH]c3=O)[nH]c2c1</smiles>

Figure 9. Receptor tyrosine kinase (RTK) inhibitors. 


\subsection{1,1,2-Triarylolefine Derivatives}

A group of 1,1,2-triarylolefines were patented as estrogen receptor antagonists (25, Figure 10). Most of the synthesized compounds of this group had high anti-estrogenic effects with minimal or no estrogen receptor agonist activity [47].

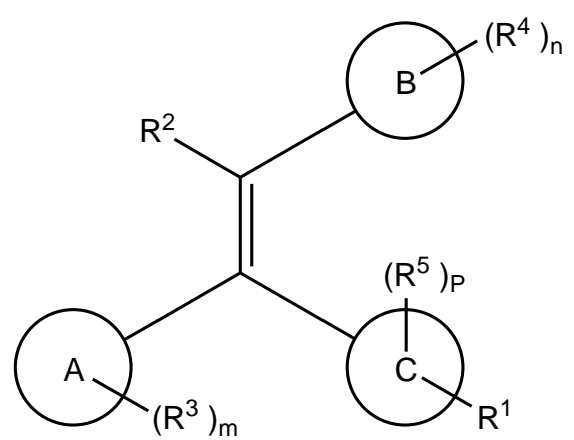

Ring A, B, C: indanyl, indenyl, naphtyl, 5- or 6-membered monocyclic heteroaryl $\mathrm{R}^{1}$ : tetrazole, optionally substituted piperidinyl

$\mathrm{R}^{2}$ : halogen, $-\mathrm{NO}_{2},-\mathrm{CN}$

$\mathrm{R}^{3}$ : halogen, $-\mathrm{NO}_{2},-\mathrm{CN},-\mathrm{OH},-\mathrm{OR},-\mathrm{CO}_{2} \mathrm{R}$

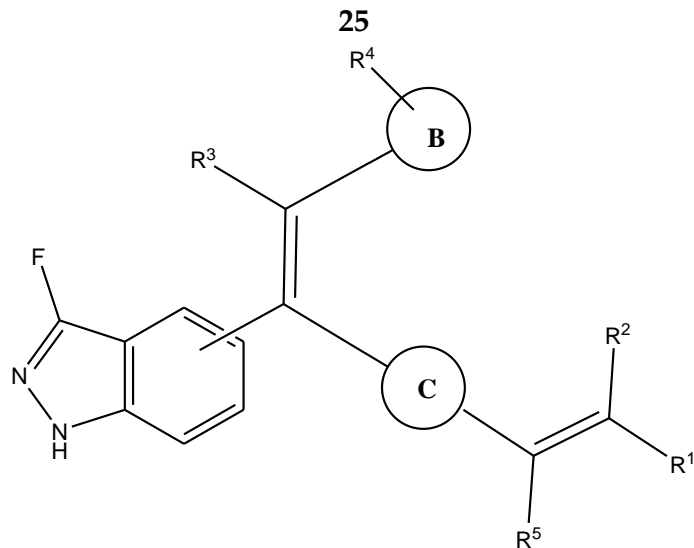

Ring B and C: phenyl, naphtyl, 5-membered monocyclic heteroaryl

$\mathrm{R}^{1}$ : $-\mathrm{C}(=\mathrm{O})-\mathrm{Z}$, carboxylic acid bioisostere $(\mathrm{Z}=\mathrm{OH}, \mathrm{OR},-\mathrm{NR})$

$\mathrm{R}^{2}$ : $\mathrm{C}_{1}-\mathrm{C}_{6}$ alkyl, $\mathrm{C}_{1}-\mathrm{C}_{6}$ fluoroalkyl

$\mathrm{R}^{3}$ : $\mathrm{H}$, alkyl or halogen

$\mathrm{R}^{4}$ : $\mathrm{H}$, halogen, $-\mathrm{CN},-\mathrm{OH},-\mathrm{OR}$

$\mathrm{R}^{5}$ and $\mathrm{R}^{6}: \mathrm{H}, \mathrm{C}_{1}-\mathrm{C}_{4}$ alkyl or halogen

Figure 10. 1,1,2-Triarylolefine.

Relating to the patent mentioned above, some new compounds were patented by Smith et al. as estrogen receptor modulators in 2015 [48,49]. This patent with formula 26 (Figure 10) showed that these compounds diminished the effects of estrogen at estrogen receptors and are useful for the treatment ER-related diseases. These compounds were tested in different cells related to estrogen and were tested in a clinical trial, demonstrating good results and high affinity to the estrogen receptor.

\subsection{Aptamer Modulators of Estrogen Receptors}

Shi Hua et al. [50] patented a nucleic acid aptamer molecule that includes a domain that binds to an estrogen receptor. Examples of aptamer molecules include those that bind to ER $\alpha$ and those that bind to ER $\beta$. These compounds have a high affinity to the estrogen receptor; therefore, this strategy can be used for patients that have estrogen-dependent cancer. 


\section{Tamoxifen Analogues}

A new series of novel tamoxifene analogues were evaluated for their anti-proliferative activity on breast cancer (MCF-7) and their activity was comparable or even higher than tamoxifen. These derivatives maintained the triarylethylene skeleton of tamoxifen having OH groups at the para position of the phenyl rings of tamoxifen and substituted the side chain of tamoxifen with an amide side chain. One of the most active compounds in this series, such as 27 (Figure 11), had anti-proliferative activity about four times higher than tamoxifen [51].

Recently, prodigiosene (Figure 12) conjugates of the tamoxifen analogue (29, Figure 11) and estrone (28, Figure 11) were reported. Prodigiosenes constitute a class of tripyrrolic compounds based on the natural product prodigiosin that share a common 4-methoxypyrrolyldipyrrin core unit. They have demonstrated anticancer activities [52,53]. Conjugating prodigiosenes to a molecule that already possesses selectivity toward the tumor should help to deliver the drug at a specific site [54-63]. Between these two compounds, the prodigiosin conjugates with the tamoxifen analogue (29, Figure 11) displayed excellent growth inhibition against the ER-positive cell line MCF-7, with better activity than tamoxifen itself against this cell line [64].<smiles>CCC(=C(c1ccc(O)cc1)c1ccc(O)cc1)c1ccc(NC(=O)C(C)C)cc1</smiles>

27<smiles>CCC(=C(c1ccc(O)cc1)c1ccc(OCCNC)cc1)c1ccccc1</smiles><smiles>COc1cc(-c2ccc[nH]2)[nH]c1/C=C1\N=C(C)C(C(=O)[GaH]C(=O)Oc2ccc3c(c2)CCC2C3CCC3(C)C(=O)CCC23)=C1C</smiles>

28<smiles>CC/C(=C(\c1ccccc1)c1ccc(OCCN(C)c2ccc([N+](=O)[O-])c3nonc23)cc1)c1ccccc1</smiles>

31<smiles>CC/C(=C(\c1ccccc1)c1ccc(C)cc1)c1ccc(OC(=O)C(=O)OC(=O)C2=C(C)/C(=C/c3[nH]c(-c4ccc[nH]4)cc3OC)N=C2C)cc1</smiles>

29<smiles>CN(C)CCOc1ccc(C(=C(F)c2ccccc2)c2ccc(O)cc2)cc1</smiles>

32<smiles>CC(=C(c1ccc(F)cc1)c1ccc(OCCN2C=CNCC2)cc1)c1ccccc1</smiles>

Figure 11. Tamoxifen analogues.

Another class of antagonists is the selective estrogen receptor down-regulators (SERDs). This class of compounds binds to ER and induces the rapid down-regulation of ER [65-68] and they have no agonistic activity in any tissues. SERDs are divided into two groups based on their chemical structures. One is steroidal compounds, such as fulvestrant (Figure 12), which has a steroidal structure with 
a long alkyl side chain at the $7 \alpha$ position of the 17ß-estradiol core [68-70]. The other group contains non-steroidal compounds, such as GW5638 (Figure 12). The structure of GW5638 is similar to tamoxifen and contains an acrylic acid side chain extending from the triphenylethylene core [71]. Shoda et al. [72] reported the design and synthesis of tamoxifen derivatives that induced down-regulation of the ER. Accordingly, a new series of tamoxifen derivatives with long alkyl chains was designed. Among them, compound 30 (Figure 11) had a strong antagonist effect.

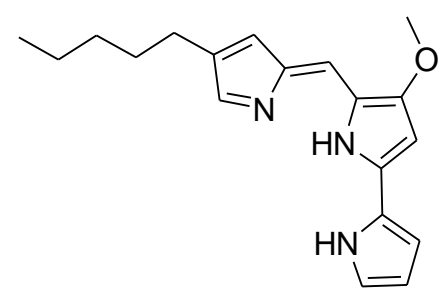

prodigiosene

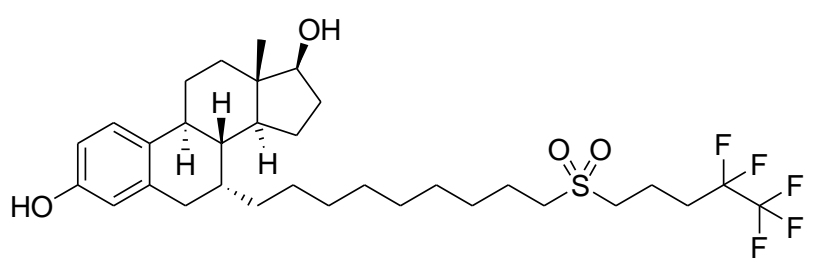

fulvestrant<smiles>CC/C(=C(\c1ccc(O)cc1)c1ccc(/C=C/C(=O)O)cc1)c1ccccc1</smiles>

Figure 12. Estrogen ligands.

In this regard, a series of novel fluorescent tamoxifen derivatives (FLTX1) were also reported as unique and SERM-like. Compound $\mathbf{3 1}$ (Figure 11), as a novel fluorescent (FLTX1), specifically labels intracellular tamoxifen-binding sites, including $\mathrm{ER} \alpha$, and displays unique pharmacological properties both in vitro and in vivo. FLTX1 exhibits the potent anti-estrogenic properties of tamoxifen in breast cancer cells without the estrogenic agonistic effect on the uterus [73].

Malo-Forest et al. [74] reported fluorinated derivatives of tamoxifen. The activities of these fluorinated analogues are similar or better than tamoxifen and among them, compound 32 (Figure 11) was the most active on the MCF7 cell line. In particular, as opposed to tamoxifen, both geometrical isomers behave similarly. This behavior may be due to in vitro isomerization of the compounds.

Abdellatif et al. [75] also showed that replacement of the dimethylamino group in tamoxifen for piperazino or $\mathrm{N}$-methylpiperazino and by changing the ethyl group by methyl substitution of the phenyl ring with a fluorine atom had excellent anti-proliferative activity on the MCF-7 cell line. Among these derivatives, compound 33 (Figure 11) showed the best results.

Cho et al. [76] patented compositions and methods for covalently bonding a polycarboxylic fatty acid and SERD as shown in Scheme 1. The conjugated compounds are useful for increasing solubility of the SERD as well as targeting the SERD to a solid tumor. Compounds have been shown to be interestingly efficacious against tamoxifen-resistant tumors. Currently, there is only one approved drug that binds to estrogen receptors for use in patients suffering from tamoxifen-resistant cancer.

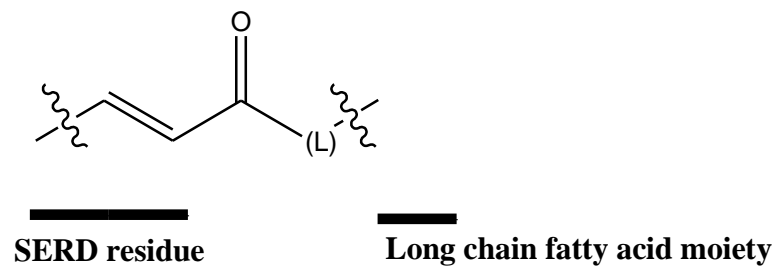

Scheme 1. Covalently bonding a polycarboxylic fatty acid and SERD. 
Preferably, the SERD is selected from the group consisting of compound 34 (Figure 13). In this group, results showed that compound 35 had the best activity, being even more potent than fulvestrant.<smiles>CC/C(=C(\c1ccccc1)c1ccc(C/C=C/C(=O)O)cc1)c1ccc(O)cc1</smiles>

34

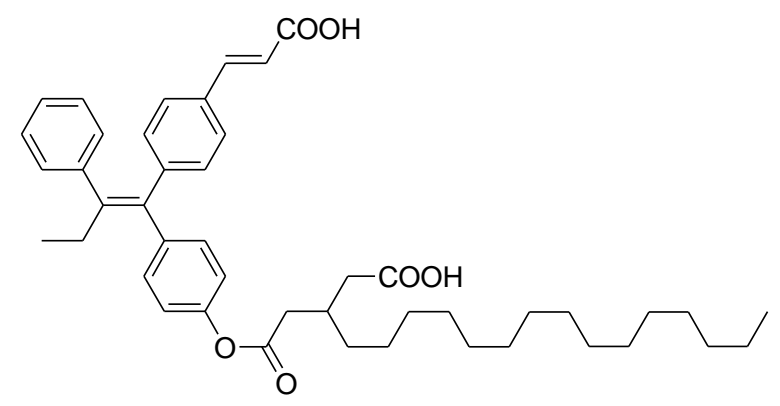

35

Figure 13. SERD (34) and fatty acid-SERD conjugate (35).

\section{Carborane Analogues}

Carboranes are man-made compounds that have no counterparts in nature. Their unique bonding, structure, and properties predetermine them to be used and tested in many applications. During the last decade it has been shown that $17 \alpha$-substituted arylestradiol sharing a lipophilic aromatic moiety displayed high affinity for binding to $E R \alpha$ and ER $\beta$ receptors [61,77-83]. As a result, Sedlak et al. [84] reported a new series of $17 \alpha$-(carboranylalkyl)estradiols as ligands for estrogen receptors $\alpha$ and $\beta$. Results showed that all of the tested compounds (Figure 14) had estrogenic activity, although none of them were able to fully activate either ER like $17 \beta$-estradiol. Relative transcription activity (RTA) is shown in Table 1. Results also showed that compound 37a is 30 times more selective for ER $\alpha$ than $\mathrm{ER} \beta$ and it is the most potent ligand for ER $\alpha$ among the tested compounds. They also showed that the length and the position of the double bond in the alkenyl linker are important for the affinity of the ligand to the receptor. Smaller carborane groups require shorter linkers to efficiently activate ERs.

A new series of fluorinated carboranyl phenols were also reported as ER $\beta$ selective ligands. Compound 38 (Figure 15) in this series displayed 8.5-fold greater selectivity for ER $\beta$. Therefore, introduction of a fluorine atom at the 9-position of the m-carborane cage reduced the ER $\alpha$ binding affinity [85].<smiles>[B]C/C=C/[C@H](O)[C@@]1(O)CCC2[C]1CCC1c3ccc(O)cc3CCC21</smiles>

36a, $\mathrm{n}=137 \mathrm{a}, \mathrm{n}=0, \mathrm{CB}=\mathrm{O}-\mathrm{CB}$

36b, $\mathrm{n}=137 \mathrm{~b}, \mathrm{n}=0, \mathrm{CB}=\mathrm{m}-\mathrm{CB}$

36c, $\mathrm{n}=137 \mathrm{c}, \mathrm{n}=0, \mathrm{CB}=\mathrm{S}-\mathrm{CoCB}_{2}$

36d, $n=137 d, n=0, C B=S S-C o C B 2$

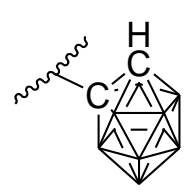

$\mathrm{O}-\mathrm{CB}$

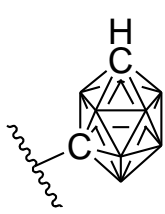

$\mathrm{m}-\mathrm{CB}$

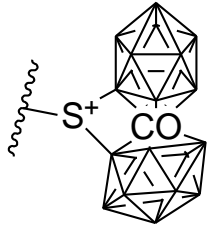

$\mathrm{S}-\mathrm{CoCB}_{2}$

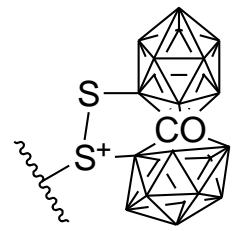

$\mathrm{SS}-\mathrm{CoCB}_{2}$

Figure 14. 17 $\alpha$-Carboranylalkylestradiols. 
Table 1. Activation of steroid receptors by carboranyl compounds.

\begin{tabular}{ccc}
\hline Compound & RTA(\%) ER $\boldsymbol{\alpha}$ & RTA(\%) ER $\boldsymbol{\beta}$ \\
\hline Agonist & 100 & 100 \\
36a & 24 & 26 \\
36b & 52 & 35 \\
36c & 20 & 16 \\
36d & 53 & 43 \\
37a & 58 & 40 \\
37b & 71 & 63 \\
37c & 16 & 14 \\
37d & 31 & 27 \\
\hline
\end{tabular}

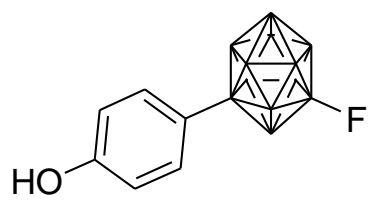

38

Figure 15. Fluorinated carborane as ER $\beta$ selective.

Ogawa et al. [86] designed and synthesized novel estrogen receptor modulators containing various hydrophobic bent-core structures. Previously discovered m-carborane derivative (39, Figure 16) displayed ER partial agonistic activity in ER $\alpha$ trans activation assays. In this series, compounds with pseudo cyclic, tetrahydropyrimidinone, m-benzene, adamantine, and 9,10-dimethyl-m-carborane were synthesized. Among them, compound 44 with a 9,10-dimethyl-m-carborane cage showed a greater ER-binding affinity than compound 39 with two methyl groups into the m-carborane cage. Compound 39 had an increase of Hansch hydrophobic value ( $\pi$ value) $[87,88]$.

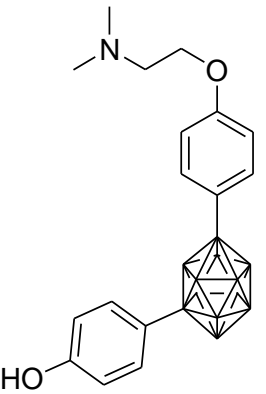

39<smiles>CN(C)CCOc1ccc(-c2cccc(-c3ccc(O)cc3)c2)cc1</smiles>

42<smiles>CN(C)CCOc1ccc(/C(O)=C/C(=O)c2ccc(O)cc2)cc1</smiles>

40<smiles>CN(C)CCOc1ccc(C23CC4CC(CC(c5ccc(O)cc5)(C4)C2)C3)cc1</smiles>

43<smiles>CN(C)CCOc1ccc(N2CCCN(c3ccc(O)cc3)C2=O)cc1</smiles>

41

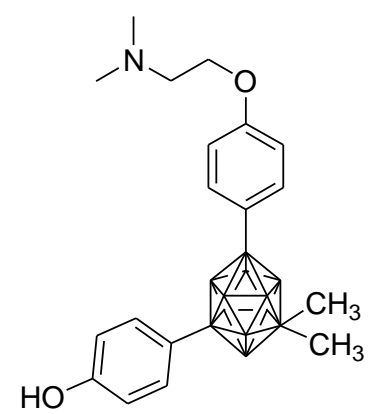

44

Figure 16. Hydrophobic bent-core structures. 


\section{Metal Complexes}

Estrogenic steroid conjugates possessing metal chelates at the $17 \alpha$-position represent an attractive delivery vector as a targeting strategy [89-92]. In this regard, Zhang et al. synthesized a new series of estrogen-derived metal complexes and applied the squaramide structure as the core of the metal binding unit. Results showed that all of the compounds in this series were agonists on ER $\alpha$. Compared to the neutral free ligand (45, Figure 17), the binding affinity of compound 46a-c for ER $\alpha$ increased, while the binding affinity of $46 \mathbf{a}-\mathbf{c}$ for ER $\beta$ all decreased [93].

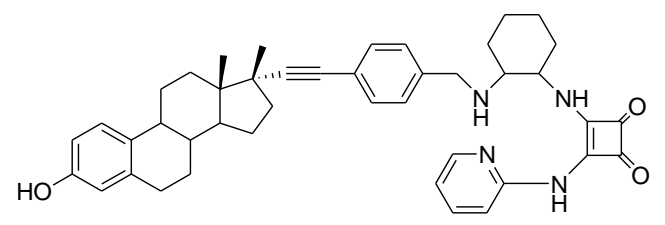

45

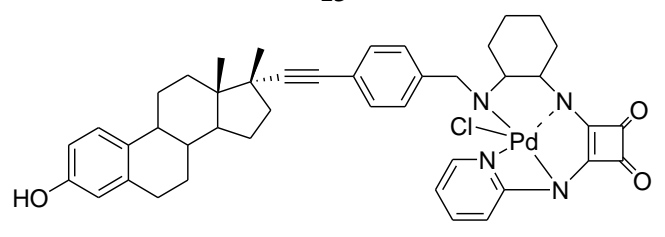

$46 a$



$46 b$

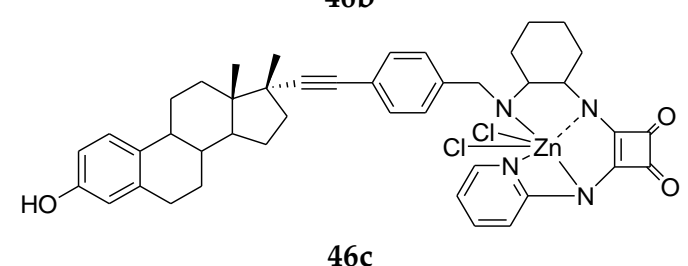

Figure 17. Novel type of targeting agents for ER.

Recently, new ferrocenyl compounds with different alkyl chain lengths were synthesized and evaluated against hormone-dependent breast cancer cells. Seven new ferrocenyl compounds having different chain lengths (suberic, adipic, succinic) were synthesized and all of them displayed strong anti-proliferative activity against hormone-dependent and independent breast cancer cell lines. Interestingly, among this series, compound 47, having a succinimide group (Figure 18), was the most active compound against hormone-dependent MCF-7 breast cancer cells, presumably owing to an antagonist effect on $\mathrm{ER} \alpha$ [94].

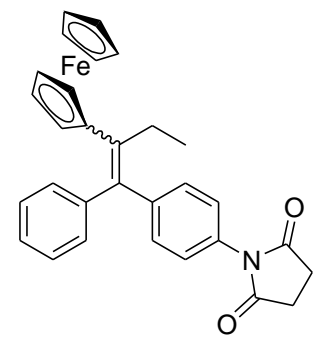

47

Figure 18. Ferrocenyl compound. 
In 2014, some thiosemicarbazone ligands and their rhenium(I) carbonyl complexes were synthesized, characterized, and their estrogen receptor binding affinities were determined (48, Figure 19). In general, all compounds displayed values of less than $50 \%$ for binding affinity for both estrogen receptor subtypes.

The results indicated that the type of halogen on the rhenium atom does not seem to have an effect on the affinity of the complex for the receptor, but the hydroxyl group at the para position of phenyl ring plays a positive role. In any case, the nature of the $R_{3}$ and $R_{5}$ groups seems to be more significant [95].



$$
\mathrm{R}_{1}=\mathrm{OMe}, \mathrm{R}_{2}=\mathrm{Me}, \mathrm{R}_{3}=\mathrm{OMe}, \mathrm{R}_{4}=\mathrm{H}, \mathrm{R}_{5}=\mathrm{H}, \mathrm{Me}, \mathrm{Ph}, \mathrm{X}=\mathrm{Cl}, \mathrm{Br}
$$

48

Figure 19. Rhenium(I) thiosemicarbazone complexes.

\section{Conclusions}

Since activation of $E R \alpha$ is associated with proliferative responses in the mammary gland and in the uterus, the development of selective ER $\alpha$ antagonists or selective ER $\alpha$ ligands with mixed tissue-selective agonist/antagonist activity is a promising strategy for the production of new therapeutic agents. In contrast, the therapeutic potentials of ER $\beta$ agonists for the treatment of other pathologies such as prostate cancer or cardiovascular diseases attract researchers to develop selective ER $\beta$ agonists as safe and efficacious drugs. This review provides an overview and update of compounds that have been recently reported as estrogen receptor ligands, with a particular focus on their structure-activity relationships and their potential clinical applications. The compounds were classified based on chemical structure in steroidal and non-steroidal ligands. Atypical ER ligands including carborane analogues and estrogenic metal complexes were also described.

SERMs are compounds that exhibit tissue-specific estrogen receptor agonist or antagonist activity [2]. They represent a diverse group of molecules with varying levels of estrogen agonist and antagonist activity in different tissues. With unique and different patterns of ER subtype expression seen in the breast, bone, CNS, and cardiovascular system, ER ligands including SERMs can exert a wide range of physiological effects related to both pathological and therapeutic processes. The most important clinical successes achieved in the ER ligand field over the past decades mainly involve SERMs or ER $\alpha$ antagonists which are used in the treatment of estrogen-related cancers such as breast cancer, osteoporosis, and cardiovascular diseases [47]. The classical treatment in ER-positive breast cancer is oral tamoxifen as a first-generation SERM. However, over time or by chance mutation, ER-positive breast cancer not only becomes resistant to tamoxifen, as tamoxifen becomes an agonist which induces proliferation. Unlike SERMs like tamoxifen, SERDs are not ER agonists which limit side effects throughout the body such as endometrial hyperplasia or uterotrophy and bone demineralization which make them much more tolerable therapies. Unfortunately, there is only one approved hormonal estrogen receptor-targeted medication for tamoxifen-resistant cancer, the SERD fulvestrant. Due to solubility issues of fulvestrant, it has to be prepared in oil and used as an IM injection which is extremely painful and unpleasant for patients. Therefore, there is a need to develop new SERDs with oral activity as alternative treatment for patients suffering from tamoxifen-resistant cancers. Conjugation of a SERD and a polycarboxylic fatty acid is a good strategy to form fatty acid-drug conjugate compounds. The conjugate compounds are useful for increasing solubility of the SERDs 
as well as targeting the SERD to solid tumors. In particular, the compounds have been shown to be interestingly efficacious against tamoxifen-resistant tumors. The authors believe that in the near future, several new SERDs will be introduced in this field for the treatment of tamoxifen-resistant cancers. In fact, new orally bioavailable SERDs hold promise as a next generation therapy for the treatment of ER-positive breast cancer as monotherapy as well as in combination with agents that target other pathways involved in endocrine-resistant states. In addition to SERDs, a great deal of attention is presently being paid to ER $\beta$ agonists. Recently, a remarkable rise of interest in developing ER modulators displaying the same beneficial effects of estrogens without the adverse side effects was observed after the discovery of a second ER subtype, ER $\beta$. Therefore, the recent literature has focused on selective ER $\beta$ ligands as highly promising targets for the treatment of some types of cancer, as well as for cardiovascular and inflammatory bowel diseases. Because of the high therapeutic potential of ER $\beta$ ligands, we should expect that in the coming years more ER $\beta$-selective agonists will be launched in the market for the treatment of different pathologies such as breast cancer, prostate cancer, colorectal cancer, cardiovascular diseases, and neurodegenerative diseases.

Author Contributions: This paper has two authors with the same contribution.

Conflicts of Interest: The authors declare no conflict of interest.

\section{References}

1. Maximov, P.Y.; Lee, T.M.; Jordan, V.C. The discovery and development of selective estrogen receptor modulators (SERMs) for clinical practice. Curr. Clin. Pharmacol. 2013, 8, 135. [CrossRef] [PubMed]

2. Jordan, V.C. Selective estrogen receptor modulation: A personal perspective. Cancer Res. 2001, 61, 5683-5687. [CrossRef]

3. Paterni, I.; Granchi, C.; Katzenellenbogen, J.A.; Minutolo, F. Estrogen receptors alpha (ER $\alpha$ ) and beta (ER $\beta)$ : Subtype-selective ligands and clinical potential. Steroids 2014, 90, 13-29. [CrossRef] [PubMed]

4. Chang, E.C.; Frasor, J.; Komm, B.; Katzenellenbogen, B.S. Impact of estrogen receptor $\beta$ on gene networks regulated by estrogen receptor $\alpha$ in breast cancer cells. Endocrinology 2006, 147, 4831-4842. [CrossRef] [PubMed]

5. Archer, J. Estrogen and mood changes via CNS activity. Menopausal Med. 1999, 7, 4-8.

6. Walf, A.A.; Frye, C.A. Estradiol reduces anxiety-and depression-like behavior of aged female mice. Physiol. Behav. 2010, 99, 169-174. [CrossRef] [PubMed]

7. Vitale, C.; Mendelsohn, M.E.; Rosano, G.M. Gender differences in the cardiovascular effect of sex hormones. Nat. Rev. Cardiol. 2009, 6, 532-542. [CrossRef] [PubMed]

8. Guetta, V.; Cannon, R.O. Cardiovascular effects of estrogen and lipid-lowering therapies in postmenopausal women. Circulation 1996, 93, 1928-1937. [CrossRef] [PubMed]

9. Nilsson, S.; Gustafsson, J.Å. Estrogen receptors: Therapies targeted to receptor subtypes. Clin. Pharmacol. Ther. 2011, 89, 44-55. [CrossRef] [PubMed]

10. Lerner, L.J.; Jordan, V.C. Development of antiestrogens and their use in breast cancer: Eighth Cain memorial award lecture. Cancer Res. 1990, 50, 4177-4189. [PubMed]

11. Jordan, V.C. Antiestrogens and selective estrogen receptor modulators as multi-functional medicines 1. Receptor interactions. J. Med. Chem. 2003, 46, 883-908. [CrossRef] [PubMed]

12. Jordan, V.C. Antiestrogens and selective estrogen receptor modulators as multi-functional medicines 2. Clinical considerations and new agents. J. Med Chem. 2003, 46, 1081-1111. [CrossRef]

13. Minutolo, F.; Macchia, M.; Katzenellenbogen, B.S.; Katzenellenbogen, J.A. Estrogen receptor $\beta$ ligands: Recent advances and biomedical applications. Med. Res. Rev. 2011, 31, 364-442. [CrossRef] [PubMed]

14. Paterni, I.; Bertini, S.; Granchi, C.; Macchia, M.; Minutolo, F. Estrogen receptor ligands: A patent review update. Expert Opin. Ther. Pat. 2013, 23, 1247-1271. [CrossRef] [PubMed]

15. Nilsson, S.; Koehler, K.F.; Gustafsson, J.-Å. Development of subtype-selective oestrogen receptor-based therapeutics. Nat. Rev. Drug Discov. 2011, 10, 778-792. [CrossRef] [PubMed]

16. Zhang, J.-X.; Labaree, D.C.; Hochberg, R.B. Synthesis of $11 \beta$-ether-17 $\alpha$-ethinyl-3,17 $\beta$-estradiols with strong ER antagonist activities. Chin. Chem. Lett. 2014, 25, 567-570. [CrossRef] 
17. Griggs, J.; Metcalfe, J.C.; Hesketh, R. Targeting tumour vasculature: The development of combretastatin A4. Lancet Oncol. 2001, 2, 82-87. [CrossRef]

18. Parihar, S.; Kumar, A.; Chaturvedi, A.K.; Sachan, N.K.; Luqman, S.; Changkija, B.; Manohar, M.; Prakash, O.; Chanda, D.; Khan, F.; et al. Synthesis of combretastatin A4 analogues on steroidal framework and their anti-breast cancer activity. J. Steroid Biochem. Mol. Biol. 2013, 137, 332-344. [CrossRef] [PubMed]

19. Haines, D.R.; Tseng, C.K.; Marquez, V.E. Synthesis and biological activity of unsaturated carboacyclic purine nucleoside analogues. J. Med. Chem. 1987, 30, 943-947. [CrossRef] [PubMed]

20. Huryn, D.M.; Okada, M. AIDS-driven nucleoside chemistry. Chem. Rev. 1992, 92, 1745-1768. [CrossRef]

21. Tuncbilek, M.; Guven, E.B.; Onder, T.; Cetin Atalay, R. Synthesis of novel 6-(4-substituted piperazine-1-yl)9-(b-D-ribofuranosyl) purine derivatives, which lead to senescence-induced cell death in liver cancer cells. J. Med. Chem. 2012, 55, 3058-3065. [CrossRef] [PubMed]

22. Norman, T.C.; Gray, N.S.; Koh, J.T.; Schultz, P.G. A structure-based library approach to kinase inhibitors. J. Am. Chem. Soc. 1996, 118, 7430-7431. [CrossRef]

23. Legraverend, M.; Grierson, D.S. The purines: Potent and versatile small molecule inhibitors and modulators of key biological targets. Bioorg. Med. Chem. 2006, 14, 3987-4006. [CrossRef] [PubMed]

24. Bressi, J.C.; Choe, J.; Hough, M.T.; Buckner, F.S.; VanVoorhis, W.C.; Verlinde, C.L.; Hol, W.G.; Gelb, M.H. Adenosine analogues as inhibitors of Trypanosoma brucei phosphoglycerate kinase: Elucidation of a novel binding mode for a 2-amino-N6-substituted adenosine. J. Med. Chem. 2000, 43, 4135-4150. [CrossRef] [PubMed]

25. Bavetsias, V.; Large, J.M.; Sun, C.; Bouloc, N.; Kosmopoulou, M.; Matteucci, M.; Wilsher, N.E.; Martins, V.; Reynisson, J.; Atrash, B.; et al. Imidazo[4,5-b]pyridine derivatives as inhibitors of aurora kinases: Lead optimization studies toward the identification of an orally bioavailable preclinical development candidate. J. Med. Chem. 2010, 53, 5213-5228. [CrossRef] [PubMed]

26. Boumendjel, A.; Nicolle, E.; Moraux, T.; Gerby, B.; Blanc, M.; Ronot, X.; Boutonnat, J. Piperazino-benzopyranones and phenalkylaminobenzopyranones: Potent inhibitors of breast cancer resistance protein (ABCG2). J. Med. Chem. 2005, 48, 7275-7281. [CrossRef] [PubMed]

27. Huang, L.; Xu, H.; Yang, Z.; Zheng, Y.; Liu, H. Synthesis and anticancer activity of novel C6-piperazine substituted purine steroid-nucleosides analogues. Steroids 2014, 82, 1-6. [CrossRef] [PubMed]

28. Huang, L.; Li, Y.; Xu, H.; Zheng, Y.; Liu, H. Synthesis and biological evaluation of novel C6-cyclo secondary amine substituted purine steroid-nucleosides analogues. Steroids 2014, 85, 13-17. [CrossRef] [PubMed]

29. Bandyopadhyay, D.; Rivera, G.; Sanchez, J.L.; Rivera, J.; Granados, J.C.; Guerrero, A.M.; Chang, F.-M.; Dearth, R.K.; Short, J.D.; Banik, B.K. Bismuth nitrate-induced novel nitration of estradiol: An entry to new anticancer agents. Eur. J. Med. Chem. 2014, 82, 574-583. [CrossRef] [PubMed]

30. Longatto Filho, A.; Lopes, J.M.; Schmitt, F.C. Angiogenesis and breast cancer. J. Oncol. 2010, $2010,576384$. [CrossRef]

31. Tang, Z.; Niu, S.; Liu, F.; Lao, K.; Miao, J.; Ji, J.; Wang, X.; Yan, M.; Zhang, L.; You, Q.; et al. Synthesis and biological evaluation of 2,3-diaryl isoquinolinone derivatives as anti-breast cancer agents targeting ER $\alpha$ and VEGFR-2. Bioorg. Med. Chem. Lett. 2014, 24, 2129-2133. [CrossRef] [PubMed]

32. Matsushima, A.; Liu, X.; Okada, H.; Shimohigashi, M.; Shimohigashi, Y. Bisphenol AF is a full agonist for the estrogen receptor ERalpha but a highly specific antagonist for ERbeta. Environ. Health Perspect. 2010, 118, 1267-1272. [CrossRef] [PubMed]

33. Sumbayev, V.V.; Jensen, J.K.; Hansen, J.A.; Andreasen, P.A. Novel modes of oestrogen receptor agonism and antagonism by hydroxylated and chlorinated biphenyls, revealed by conformation-specific peptide recognition patterns. Mol. Cell. Endocrinol. 2008, 287, 30-39. [CrossRef] [PubMed]

34. Showell, G.A.; Mills, J.S. Chemistry challenges in lead optimization: Silicon isosteres in drug discovery. Drug Discov. Today 2003, 8, 551-556. [CrossRef]

35. Franz, A.K.; Wilson, S.O. Organosilicon molecules with medicinal applications. J. Med. Chem. 2012, 56, 388-405. [CrossRef] [PubMed]

36. Fujii, S.; Miyajima, Y.; Masuno, H.; Kagechika, H. Increased Hydrophobicity and Estrogenic Activity of Simple Phenols with Silicon and Germanium-Containing Substituents. J. Med. Chem. 2012, 56, 160-166. [CrossRef] 
37. Nakamura, M.; Makishima, M.; Hashimoto, Y. Development of silicon-containing bis-phenol derivatives as androgen receptor antagonists: Selectivity switching by C/Si exchange. Bioorg. Med. Chem. 2013, 21, 1643-1651. [CrossRef] [PubMed]

38. Maruyama, K.; Nakamura, M.; Tomoshige, S.; Sugita, K.; Makishima, M.; Hashimoto, Y.; Ishikawa, M. Structure-activity relationships of bisphenol A analogs at estrogen receptors (ERs): Discovery of an ER $\alpha$-selective antagonist. Bioorg. Med. Chem. Lett. 2013, 23, 4031-4036. [CrossRef] [PubMed]

39. Ohta, K.; Chiba, Y.; Kaise, A.; Endo, Y. Structure-activity relationship study of diphenylamine-based estrogen receptor (ER) antagonists. Bioorg. Med. Chem. 2015, 23, 861-867. [CrossRef] [PubMed]

40. Chandrasekharan, S.; Bhaskar, B.; Muthiah, R.; Chandrasekharan, A.K.; Ramamurthy, V. Estrogenic effect of three substituted deoxybenzoins. Steroids 2013, 78, 147-155. [CrossRef] [PubMed]

41. Forman, B.; Yu, D. Ligands for Estrogen Related Receptors and Methods for Synthesis of Said Ligands. U.S. Patent 20,130,131,340, 23 May 2013.

42. Wallace, D.J.; Reamer, R.A. New synthesis of a selective estrogen receptor modulator using an enatioselective phosphine-mediated $2+3$ cycloaddition. Tetrahedron Lett. 2013, 54, 4425-4428. [CrossRef]

43. Clark, J.A.; Alves, S.; Gundlah, C.; Rocha, B.; Birzin, E.T.; Cai, S.J.; Flick, R.; hayes, E.; Ho, K.; Warrier, S.; et al. Selective estrogen receptor-beta (SERM-beta) compounds modulate raphe nuclei tryptophan hydroxylase-1 (TPH-1) mRNA expression and cause antidepressant-like effects in the forced swim test. Neuropharmacology 2012, 63, 1051-1063. [CrossRef] [PubMed]

44. Chen, H.; Li, S.; Yao, Y.; Zhou, L.; Zhao, J.; Gu, Y.; Wang, K.; Li, X. Design, synthesis, and anti-tumor activities of novel triphenylethylene-coumarin hybrids, and their interactions with Ct-DNA. Bioorg. Med. Chem. Lett. 2013, 23, 4785-4789. [CrossRef] [PubMed]

45. Smith, N.D.; Govek, S.P.; Kahraman, M.; Nagasawa, J.Y.; Lai, A.G.; Bonnefous, C. Fluorinated Estrogen Receptor Modulators and Uses Thereof. U.S. Patent 20,150,005,286, 1 January 2015.

46. Yovine, A.; Squires, M.; Reddick, C.; Zhang, Y. Combination of a RTK Inhibitor with an Anti-Estrogen and Use Thereof for the Treatment of Cancer. Patent WO2,013,116,293, 8 August 2013.

47. Smith, N.D.; Kahraman, M.; Govek, S.P.; Nagasawa, J.Y.; Lai, A.G.; Julien, J.D.; Herbert, M.R.; Bonnefous, C.; Douglas, K.L. Estrogen Receptor Modulators and Uses Thereof. U.S. Patent 20,130,231,333, 5 September 2013.

48. Smith, N.D.; Govek, S.P.; Kahraman, M.; Julien, J.D.; Nagasawa, J.Y.; Douglas, K.L.; Bonnefous, C.; Lai, A.G. Estrogen Receptor Modulators and Uses Thereof. U.S. Patent 20,150,105,403, 28 January 2015.

49. Hager, J.H.; Chow maneval, E.; Smith, N.D.; Friedman, L.; Sampath, D. Therapeutic Combinations with Estrogen Receptor Modulators. Patent WO2,015,136,016, 10 December 2015.

50. Shi, H.; Xu, D.; Chatakonda, V.K. Aptamer Modulators of Estrogen Receptors. U.S. Patent 20,150,031,754, 29 January 2015.

51. Christodoulou, M.S.; Fokialakis, N.; Passarella, D.; García-Argáez, A.N.; Gia, O.M.; Pongratz, I.; Dalla Via, L.; Haroutounian, S.A. Synthesis and biological evaluation of novel tamoxifen analogues. Bioorg. Med. Chem. 2013, 21, 4120-4131. [CrossRef] [PubMed]

52. Fürstner, A. Chemistry and biology of roseophilin and the prodigiosin alkaloids: A survey of the last 2500 years. Angew. Chem. Int. Ed. 2003, 42, 3582-3603. [CrossRef] [PubMed]

53. Pandey, R.; Chander, R.; Sainis, K. Prodigiosins as anti cancer agents: Living upto their name. Curr. Pharm. Des. 2009, 15, 732-741. [CrossRef] [PubMed]

54. Mazza, M.; Uchegbu, I.; Schätzlein, A. Cancer and the blood-brain barrier: 'Trojan horses' for courses? Br. J. Pharmacol. 2008, 155, 149-151. [CrossRef] [PubMed]

55. Spradau, T.W.; Katzenellenbogen, J.A. Ligands for the estrogen receptor, containing cyclopentadienyltricarbonylrhenium units. Bioorg. Med. Chem. Lett. 1998, 8, 3235-3240. [CrossRef]

56. Perron, V.; Rabouin, D.; Asselin, É.; Parent, S.; C-Gaudreault, R.; Bérubé, G. Synthesis of 17 $\beta$-estradiol-linked platinum (II) complexes and their cytocidal activity on estrogen-dependent and-independent breast tumor cells. Bioorg. Chem. 2005, 33, 1-15. [CrossRef] [PubMed]

57. Van Themsche, C.; Parent, S.; Leblanc, V.; Descôteaux, C.; Simard, A.-M.; Bérubé, G.; Asselin, E. VP-128, a novel oestradiol-platinum (II) hybrid with selective anti-tumour activity towards hormone-dependent breast cancer cells in vivo. Endocr.-Relat. Cancer 2009, 16, 1185-1195. [CrossRef] [PubMed]

58. Provencher-Mandeville, J.; Debnath, C.; Mandal, S.K.; Leblanc, V.; Parent, S.; Asselin, É.; Bérubé, G. Design, synthesis and biological evaluation of estradiol-PEG-linked platinum (II) hybrid molecules: Comparative molecular modeling study of three distinct families of hybrids. Steroids 2011, 76, 94-103. [CrossRef] [PubMed] 
59. Cyrus, K.; Wehenkel, M.; Choi, E.Y.; Lee, H.; Swanson, H.; Kim, K.B. Jostling for Position: Optimizing Linker Location in the Design of Estrogen Receptor-Targeting PROTACs. Chem. Med. Chem. 2010, 5, 979-985. [CrossRef]

60. Gacio, A.F.; Fernandez-Marcos, C.; Swamy, N.; Dunn, D.; Ray, R. Photodynamic cell-kill analysis of breast tumor cells with a tamoxifen-pyropheophorbide conjugate. J. Cell. Biochem. 2006, 99, 665-670. [CrossRef] [PubMed]

61. El Amouri, H.; Vessieres, A.; Vichard, D.; Top, S.; Gruselle, M.; Jaouen, G. Syntheses and affinities of novel organometallic-labeled estradiol derivatives: A structure-affinity relationship. J. Med. Chem. 1992, 35, 3130-3135. [CrossRef]

62. Top, S.; El Hafa, H.; Vessieres, A.; Quivy, J.; Vaissermann, J.; Hughes, D.W.; McGlinchey, M.J.; Mornon, J.-P.; Thoreau, E.; Jaouen, G. Rhenium Carbonyl Complexes of $\beta$-Estradiol Derivatives with High Affinity for the Estradiol Receptor: An Approach to Selective OrganometallicRadiopharmaceuticals. J. Am. Chem. Soc. 1995, 117, 8372-8380. [CrossRef]

63. Tang, J.; Top, S.; Vessières, A.; Sellier, N.; Vaissermann, J.; Jaouen, G. Synthesis of $17 \alpha$-ruthenocenyl-17 $\beta$ oestradiol and its potential as a radiopharmaceutical agent. Appl. Organomet. Chem. 1997, 11, 771-781. [CrossRef]

64. Hawco, C.L.A.; Marchal, E.; Uddin, M.I.; Baker, A.E.G.; Corkery, D.P.; Dellaire, G.; Thompson, A. Synthesis and biological evaluation of prodigiosene conjugates of porphyrin, estrone and 4-hydroxytamoxifen. Bioorg. Med. Chem. 2013, 21, 5995-6002. [CrossRef] [PubMed]

65. Howell, S.J.; Johnston, S.R.D.; Howell, A. The use of selective estrogen receptor modulators and selective estrogen receptor down-regulators in breast cancer. Best Pract. Res. Clin. Endocrinol. Metab. 2004, 18, 47-66. [CrossRef] [PubMed]

66. Baumann, C.K.; Castiglione-Gertsch, M. Estrogen Receptor Modulators and Down Regulators. Drugs 2007, 67, 2335-2353. [CrossRef] [PubMed]

67. Buzdar, A.U.; Robertson, J.F. Fulvestrant: Pharmacologic profile versus existing endocrine agents for the treatment of breast cancer. Ann. Pharmacother. 2006, 40, 1572-1583. [CrossRef]

68. Bross, P.F.; Baird, A.; Chen, G.; Jee, J.M.; Lostritto, R.T.; Morse, D.E.; Rosario, L.A.; Williams, G.M.; Yang, P.; Rahman, A.; et al. Fulvestrant in postmenopausal women with advanced breast cancer. Clin. Cancer Res. 2003, 9, 4309-4317. [PubMed]

69. Howell, A.; Abram, P. Clinical development of fulvestrant ("Faslodex"). Cancer Treat. Rev. 2005, 31 (Suppl. S2), S3-S9. [CrossRef] [PubMed]

70. Robertson, J.F.; Howell, A.; Gorbunova, V.; Watanabe, T.; Pienkowski, T.; Lichinitser, M. Sensitivity to further endocrine therapy is retained following progression on first-line fulvestrant. Breast Cancer Res. Treat. 2005, 92, 169-174. [CrossRef] [PubMed]

71. Willson, T.M.; Henke, B.R.; Momtahen, T.M.; Charifson, P.S.; Batchelor, K.W.; Lubahn, D.B.; Moore, L.B.; Oliver, B.B.; Sauls, H.R. 3-[4-(1,2-Diphenylbut-1-enyl)phenyl]acrylic acid: A non-steroidal estrogen with functional selectivity for bone over uterus in rats. J. Med. Chem. 1994, 37, 1550-1552. [CrossRef] [PubMed]

72. Shoda, T.; Okuhira, K.; Kato, M.; Demizu, Y.; Inoue, H.; Naito, M.; Kurihara, M. Design and synthesis of tamoxifen derivatives as a selective estrogen receptor down-regulator. Bioorg. Med. Chem. Lett. 2014, 24, 87-89. [CrossRef] [PubMed]

73. Marrero-Alonso, J.; Morales, A.; García Marrero, B.; Boto, A.; Marín, R.; Cury, D.; Gómez, T.; Fernández-Pérez, L.; Lahoz, F.; Díaz, M. Unique SERM-like properties of the novel fluorescent tamoxifen derivative FLTX1. Eur. J. Pharm. Biopharm. 2013, 85, 898-910. [CrossRef] [PubMed]

74. Malo-Forest, B.; Landelle, G.; Roy, J.-A.; Lacroix, J.; Gaudreault, R.C.; Paquin, J.-F. Synthesis and growth inhibition activity of fluorinated derivatives of tamoxifen. Bioorg. Med. Chem. Lett. 2013, 23, 1712-1715. [CrossRef] [PubMed]

75. Abdellatif, K.R.A.; Belal, A.; Omar, H.A. Design, synthesis and biological evaluation of novel triaryl (Z)-olefins as tamoxifen analogues. Bioorg. Med. Chem. Lett. 2013, 23, 4960-4963. [CrossRef]

76. Cho, M.; Hackett, M.; Mossinghoff, G.J. Selective Estrogen Receptor Degraders for Treatment of Tamoxifen Resistant Tumors. Patent WO2,014,008,159, 9 January 2014.

77. Boivin, R.P.; Luu-The, V.; Lachance, R.; Labrie, F.; Poirier, D. Structure-Activity Relationships of $17 \alpha$-Derivatives of Estradiol as Inhibitors of Steroid Sulfatase. J. Med. Chem. 2000, 43, 4465-4478. [CrossRef] [PubMed] 
78. Salman, M.; Reddy, B.R.; Delgado, P.; Stotter, P.L.; Fulcher, L.C.; Chamness, G.C. 17 alpha-substituted analogs of estradiol for the development of fluorescent estrogen receptor ligands. Steroids 1991, 56, 375-387. [CrossRef]

79. Peters, R.H.; Crowe, D.F.; Avery, M.A.; Chong, W.K.; Tanabe, M. 17-Desoxy estrogen analogs. J. Med. Chem. 1989, 32, 1642-1652. [CrossRef] [PubMed]

80. Vichard, D.; Gruselle, M.; El Amouri, H.; Jaouen, G.; Vaissermann, J. Controlled and selective introduction of a $\mathrm{Cp} \mathrm{R}^{*} \mathrm{R}+\left(\mathrm{C} \mathrm{p}^{*}=\mathrm{C} 5 \mathrm{Me} 5\right)$ fragment to the $17 \alpha$-substituent of $17 \alpha$-phenylestradiol. Organometallics 1992, 11, 2952-2956. [CrossRef]

81. Foy, N.; Stéphan, E.; Jaouen, G. Synthesis of $17 \alpha$-4-amino-and 4-iodophenylestradiols. Tetrahedron Lett. 2000, 41, 8089-8092. [CrossRef]

82. Foy, N.; Stéphan, E.; Vessieres, A.; Salomon, E.; Heldt, J.M.; Huché, M.; Jaouen, M. Synthesis, receptor binding, molecular modeling, and proliferative assays of a series of $17 \alpha$-arylestradiols. Chem. Biol. Chem. 2003, 4, 494-503. [CrossRef] [PubMed]

83. Napolitano, E.; Fiaschi, R.; Carlson, K.E.; Katzenellenbogen, J.A. 11. beta.-Substituted Estradiol Derivatives, Potential High-Affinity Carbon-11-Labeled Probes for the Estrogen Receptor: A Structure-Affinity Relationship Study. J. Med. Chem. 1995, 38, 429-434. [CrossRef] [PubMed]

84. Sedlak, D.; Eignerova, B.; Dračínský, M.; Janoušek, Z.; Bartůněk, P.; Kotora, M. Synthesis and evaluation of $17 \alpha$-(carboranylalkyl) estradiols as ligands for estrogen receptors $\alpha$ and $\beta$. J. Organomet. Chem. 2013, 747, 178-183. [CrossRef]

85. Ohta, K.; Ogawa, T.; Kaise, A.; Endo, Y. Enhanced estrogen receptor beta (ER $\beta$ ) selectivity of fluorinated carborane-containing ER modulators. Bioorg. Med. Chem. Lett. 2013, 23, 6555-6558. [CrossRef] [PubMed]

86. Ogawa, T.; Ohta, K.; Yoshimi, T.; Yamazaki, H.; Suzuki, T.; Ohta, S.; Endo, Y. m-Carborane bisphenol structure as a pharmacophore for selective estrogen receptor modulators. Bioorg. Med. Chem. Lett. 2006, 16, 3943-3946. [CrossRef]

87. Ohta, K.; Ogawa, T.; Kaise, A.; Endo, Y. Novel estrogen receptor (ER) modulators containing various hydrophobic bent-core structures. Bioorg. Med. Chem. 2014, 22, 3508-3514. [CrossRef] [PubMed]

88. Ohta, K.; Ogawa, T.; Kaise, A.; Endo, Y. Synthesis and biological evaluation of novel m-carborane-containing estrogen receptor partial agonists as SERM candidates. Bioorg. Med. Chem. Lett. 2015, 25, 3213-3216. [CrossRef] [PubMed]

89. Lo, K.K.W.; Zhang, K.Y.; Chung, C.K.; Kwok, K.Y. Synthesis, Photophysical and Electrochemical Properties, and Protein-Binding Studies of Luminescent Cyclometalated Iridium (III) Bipyridine Estradiol Conjugates. Chem. Eur. J. 2007, 13, 7110-7120. [CrossRef] [PubMed]

90. Lo, K.K.-W.; Lee, T.K.-M.; Lau, J.S.-Y.; Poon, W.-L.; Cheng, S.-H. Luminescent biological probes derived from ruthenium (II) estradiol polypyridine complexes. Inorg. Chem. 2008, 47, 200-208. [CrossRef] [PubMed]

91. Huang, L.; Zhu, H.; Zhang, Y.; Xu, X.; Cui, W.; Yang, G.; Shen, Y.-M. Synthesis and binding affinities of Re(I) and ${ }^{99 \mathrm{~m}} \mathrm{Tc}(\mathrm{I})$-containing $16 \alpha$-substituted estradiol complexes: Models for potential breast cancer imaging agents. Steroids 2010, 75, 905-911. [CrossRef] [PubMed]

92. Hanson, R.N.; Kirss, R.; McCaskill, E.; Hua, E.; Tongcharoensirikul, P.; Olmsted, S.L.; Labaree, D.; Hochberg, R.B. Targeting the estrogen receptor with metal-carbonyl derivatives of estradiol. Bioorg. Med. Chem. Lett. 2012, 22, 1670-1673. [CrossRef] [PubMed]

93. Zhang, X.; Zuo, Z.; Tang, J.; Wang, K.; Wang, C.; Chen, W.; Li, C.; Xu, W.; Xiong, X.; Yuntai, K.; et al. Design, synthesis and biological evaluation of novel estrogen-derived steroid metal complexes. Bioorg. Med. Chem. Lett. 2013, 23, 3793-3797. [CrossRef] [PubMed]

94. Cázares-Marinero, J.; Top, S.; Jaouen, G. Synthesis and characterization of new ferrocenyl compounds with different alkyl chain lengths and functional groups to target breast cancer cells. J. Organomet. Chem. 2014, 751, 610-619. [CrossRef]

95. Nunez-Montenegro, A.; Carballo, R.; Vazquez-Lopez, E.M. Synthesis, characterization and binding affinities of rhenium(I) thiosemicarbazone complexes for the estrogen receptor (alpha/beta). J. Inorg. Biochem. 2014, 140c, 53-63. [CrossRef] [PubMed]

(C) 2016 by the authors; licensee MDPI, Basel, Switzerland. This article is an open access article distributed under the terms and conditions of the Creative Commons Attribution (CC-BY) license (http://creativecommons.org/licenses/by/4.0/). 